\title{
Individuals' Psychological Change That May Arise Based on the Use of Fifth Generation Information Technologies
}

\author{
Hanife Akgül (Corresponding author) \\ Faculty of Education, Çanakkale Onsekiz Mart University \\ Terzioğlu Campus, Çanakkale, Turkey \\ Tel: 90-505-308-0804Ｅ-mail: hanifeakgul38@gmail.com
}

Received: April 10, 2020 Accepted: May 27, 2020 Published: June 2, 2020

doi:10.5296/jei.v6i1.16738ＵRL: https://doi.org/10.5296/jei.v6il.16738

\begin{abstract}
In recent years, fifth-generation (5G) information technologies has been the subject of studies all around the world, especially in developed countries. The most salient feature of $5 \mathrm{G}$ is enabling data exchange faster compared to the latest available wireless network technology 4G. The fifth-generation information technologies, called 5G, are expected to come into effect soon. Today, in developed countries, testing is being done intended for 5G. Turkey, meanwhile, is expected to use $5 \mathrm{G}$ in 2020 . When $5 \mathrm{G}$ is fully available, the Internet of Things will be able to communicate with each other thanks to Internet, in all the areas of daily life, especially in production. In this case, people should get used to the new process. It is estimated that the adaptation process in question will be shaped according to the point of view adopted by technology. In the new potential system, it is predicted that there will be a wide range of change from production method to sense of education. With the widespread use of $5 \mathrm{G}$, in individual psychology; it is predicted that changes such as self-centered, introverted, asocial personality traits may become widespread. In this new process, the proportion of individuals living "Ideal Individuality" instead of "Real Individuality" will increase; on the other hand, the number of individuals with low Real Individuality level is expected to remain very low. In this study, psychological change that can occur in individuals with "Real Individuality", "Ideal Individuality", "Individuality Design" and "Socio-Cultural Trends" with the widespreadness of 5th Generation information technologies by using descriptive analysis and editing methods are examined.
\end{abstract}

Keywords: 5G, Fifth-generation Information technologies, Change in individual psychology 


\section{Introduction}

In the period we are in, it is seen that technology has taken place in all areas of daily life. Computers, cars, smartphones and similar gadgets have been used by people for a long time. The information and communication technologies that developed increasingly its growth rate in the $20^{\text {th }}$ century have significantly facilitated people's works. On the other hand, it can be said that technology leads to the emergence of psychological uncertainties, since modern technologies can be advantageous or disadvantageous according to their usage area, purpose and method.

First-generation (1G) wireless networks were released in 1981 (Rathod 2014), (Wikipedia, 2019). Mobile connections, the number of which increases day by day, have been replaced by a new mobile generation every ten years on average. 5G technology, which has remained on the agenda for a while, promises more reliable and faster coverage for its users. 5G networks are expected to accelerate the flow of information on the Internet of Things (Note 1) (IoT). This can be utilized by consumers and companies.

The demand for wireless networks has increased over time. Cellular wireless networks have undergone a long development period from the first-generation system to date. It is known that first-generation wireless networks are based on analog protocols (MEB, 2011). First phones of analog technology were quite large in volume and very slow in terms of processing speed. The second generation $(2 \mathrm{G})$ wireless networks that became the main topic in the early 1990's were designed to improve coverage area, sound and capacity as for digital standards. Third generation $(3 \mathrm{G})$ wireless networks were developed to download data from the Internet, to exchange video online and to provide high speed data transfer. $4 \mathrm{G}$ systems, which can be called the latest technology existing today, are linked into IP protocols.

The fifth generation (5G) communication network can be described as the continuation of the 4G long-term evolution (LTE-Long Term Evolution). Nowadays, some tests are developed for $5 \mathrm{G}$ in developed countries to partially apply it. It is expected that Turkey tests $5 \mathrm{G}$ in 2020 (Akgül, Ayer, Turşucuoğlu, \& Yıldız, 2019). According to the Ericsson Mobility Report, 5G is expected to reach 1.5 billion users, corresponding to $40 \%$ of the world's population by 2020 (Ericsson, 2019). In a study conducted by Information Handling Services Markit in 2017, it forecasted that 5G's potential global sales activity will be $\$ 12.3$ trillion in 2035 (Campbell et al., 2017: 17). It can be said that existing $4 \mathrm{G}$ wireless networks are insufficient to meet the growing market demand today.

The transition process from $4 \mathrm{G}$ to $5 \mathrm{G}$ presents difficulties on change and transformation that must take place in order or the $5 \mathrm{G}$ vision to be fully implemented. The integration of $5 \mathrm{G}$ technology with current systems, which is necessary to provide services in different application areas, is at the top of the list. In this context, $5 \mathrm{G}$ is criticized for its likely high cost and incompatibility with previous generation technologies. For example, $2 \mathrm{G}$ phones cannot connect to $3 \mathrm{G}$ or $4 \mathrm{G}$ networks. Similarly, it is estimated that $3 \mathrm{G}$ and $4 \mathrm{G}$ phones will not be able to connect to $5 \mathrm{G}$ network or there will be significant problems in connection (Akgül, 2019). 


\section{MInstitute ${ }_{\text {Mnk }}^{\text {Macrothink }}$}

The expectation that $5 \mathrm{G}$ is likely to be more expensive than the most up-to-date technology $4 \mathrm{G}$ or LTE service forces people to buy new phones and tablets. To avert this situation, a serious change is needed for the design of cellular architecture. We also need to meet $5 \mathrm{G}$ system performance requirements such as Femtocells (Note 2), hard delays, network scalability, very long battery life and environment friendly communication. Meeting these requirements and minimizing costs as well, is a difficult task (Campanaro, 2018). In addition, every new technological product that emerges with the rapid change in technology is put on the market without any time to be fully adopted even by the user group it addresses. At the last point, rapid changes and developments in $5 \mathrm{G}$ technologies require society and individuals to adapt to this new situation and process because of the fact that it will require the individual to live in an area that he has never experienced; that is, all areas where the individual lives such as houses, workplaces, schools and even the street will be integrated with cyber physical systems. The fact that man will live in such an environment that he has not experienced until now shows that this situation will have some psychological effects on people in the adaptation process.

Psychological effects are expected to take shape upon human acceptance or rejection of living with technology. Fear for the effects of technological developments on society and the environment or the use of technological tools such as computers is defined as "technophobia" (Collins English Dictionary, 2020). Technophobia is not an officially defined mental illness. It is an unnecessary and extremely fear towards technology. Generally, this fear is an irrational fear that computers, robots, artificial intelligence and weapons are developed in scientific thinking (Indus Net Technologies, 2016). Technophile, a concept that can be considered as the opposite of technophobia, can be defined as "a long-term use and adaptation of technology, a clear approach developed against technology and reflecting the quality of a particular technology" (Ronit, 2011: 5).

The positive or negative effect of the new environment that will occur with the $5 \mathrm{G}$ process on the people can be predicted with the help of the concepts of technology and technophile in parallel with the desire of people to adapt to the technology. Individuals who adopt a technophobic perspective may be adversely affected in the new period. Since information technologies currently occupy a very large area in daily life. In the new period, it can be claimed that there will be no area where information technologies are not used. In this case, it will be compulsory to use technology to continue working, earn money, read, and perhaps meet daily routine needs. Therefore, with the urge to stay away from technology or to be afraid of technology in the new process, the individual may tend to stay out of the process. In this case, it is expected that the negative perspective adopted against technology will deepen and the individual will be negatively affected from the psychological point of view. However, if the individual can develop or adopt his technological point of view, her/his interest and curiosity in technology will increase; There can be a positive development in the psychology of the individual.

In other words; in addition to the solution of technical problems for the use and dissemination of 5G technology, it is estimated that effective user individuals in the societies that can ensure the use and dissemination of these technologies will affect the psychologies positively and a 
significant change will occur in the individual psychology. It is predicted that the level of influence and change in individuals psychology who use this new technology effectively, especially in subjects such as "Individuality Design Change", "Real Individuality-Ideal Conflict and Change", "Socio-Cultural Trend Change" (Akgül \& Ayer, 2020).

As the usage of $5 \mathrm{G}$ technology has started to become widespread, the data related to the mode of influence and the level of change predicted to occur in individual psychology are analyzed in detail in the findings section.

\section{Method}

In this study, it is aimed to discuss the possible effects of the use of fifth generation (5G) information technologies on human psychology. In the study, a literature review based on secondary data has been performed. Firstly, the historical development process of $5 \mathrm{G}$ technologies has been examined. Then, by making tertiary data development study based on secondary data; depending on the development in $5 \mathrm{G}$ technologies, it has been examined whether there will be a change in individual psychology. Afterwards, using the editing method; it has been tried to examine what kind of changes may occur in individual psychology. When the method is evaluated in general; in the study, descriptive research method based on secondary and tertiary data and editing method have been used together.

\section{Results}

As a result of the literature review and analysis carried out; in the process of using $5 \mathrm{G}$ technologies, it has been determined that individual psychology might be affected both positively and negatively. Whether the impact is positive or negative may be closely related to the individual/individuals' $5 \mathrm{G}$ perspective, as well as the socio-cultural situation and approaches of societies, the level of development of the society, the state of possession or availability of technology production, technological knowledge and so on. It is determined that many factors are effective. In addition, 5G technology is expected to have positive or negative effects on the natural environment, human physical health and digital security. It is seen that the positive and negative effects that may arise with the widespread use of $5 \mathrm{G}$ technology will inevitably affect individual psychology. With the introduction of 5G technologies widely in this part of the study, the subject of whether the individual affects his/her physical health first, then the positive and/or negative effects and changes in the natural environment he lives in, and then the developments and changes in the cyber security situation will be the subject of interest and focus. Finally, with the effect of all these developments, it is expected that the individual will focus on the changes that may occur in his/her psychological state. In order to analyze the subject better, it will be useful to discuss the research data given above in detail with the stated impact order.

In the 30th APS Annual Meeting (30th APS Annual Convention) held in San Francisco, one of the most important technology centers in the world, the speakers presented their interdisciplinary studies on how technology shapes learning, attention, behavior and social life from childhood to old age. In a study conducted by human-computer interaction specialist Mark and colleagues to observe the behavior of their employees in the workplace (Michel, 
2018);

1) Working in a digital environment leads people to be polychronic, which means working simultaneously on multiple tasks,

2) People cannot fully work on more than one task at a time, people have an average attention span of about 40 seconds,

3) People tend to change attention very quickly between different sources of information after an average attention span of 40 seconds,

4) They found that new Information and Communication Technologies not only changed people's interaction with the world, but also human behavior and how the brain works.

By making use of these and similar research results; it is possible to state that the fifth generation $(5 \mathrm{G})$ information and communication technologies, which have an important place in the world agenda, are in a scope that can change not only the daily life but also the psychological structure of the individual (Akgül, 2019). In other scientific studies, claims are made that $5 \mathrm{G}$ technologies may threaten human health both physically and psychologically (Davutoğlu \& Akgül, 2019).

The Internet of Things, which falls in the components of $5^{\text {th }}$ generation $(5 \mathrm{G})$ information technologies is a globally widespread network among objects and a system that allows them to communicate with each other over this network. In this system, which will minimize human intervention, almost everything will be controlled remotely via a smartphone or a tablet. Today, autonomous devices, which have some examples under the name of "smart home", will be offered to people in a much more widespread area with $5 \mathrm{G}$ and the internet of things. It is expected that electronic devices that already emit harmful radiation to human health will create more critical conditions for human health with the use of $5 \mathrm{G}$ in the coming period. Prof. Dr. Selim Şeker, lecturer from Üsküdar University Faculty of Electrical and Electronics Department, stated that " $5 \mathrm{G}$ will cause types of cancer to increase by affecting cell growth and organs, and will inevitably affect the immune system, heart and circulation system and biological functions". Şeker also stated that "the thermal effects affect the skin as well as damaging the eye surface and the eye." (ÜHA, 2018).

International Cancer Research Agency (IARC), which operates within the World Health Organization (WHO), defines mobile phones as "possible carcinogens" (BBC, 2018). This situation can be interpreted as a hypothesis that, it is not certain that mobile phones or technological devices that emit radiation invite cancer. However, in his another study, Şeker claims that the radiation that we will be exposed to, especially with the use of 5G, is a type of radiation that the human body is not accustomed to, and this situation may cause some health problems (Nöropsikiyatri Portal1, 2019). Using 5G other technological tools in conjunction with the Internet of things, it is expected that the individual will be exposed to intense radiation in almost any environment in which they are located. "It is known that in September 2017, 180 scientists and doctors from 35 countries wanted to stop studies on $5 \mathrm{G}$ until it would be proven safe, especially for children and pregnant women." (Gerçek Hayat, 2019). 
With the introduction of all the fifth-generation information technology (5G) tools at the same time and in common cooperation together, it will be possible to access all kinds of personal data of the individual from the virtual environment. This situation can be considered advantageous in terms of enabling employees to access necessary data without time and space restrictions. However, when it is evaluated in terms of the privacy of the individual's personal data, it is likely that serious security problems will occur (Akgül, 2019). It is stated in the 2018 Global Risk Report published by the World Economic Forum that cyber violations have increased fivefold in the last two years (Ekovitrin, 2018: 115). With the introduction of $5 \mathrm{G}$ technologies at the same time and together, it is claimed that cyber-attacks can be more destructive and more widespread (Davutoğlu \& Akgül, 2019). There will be possibilities such as changing the results of the election leaking company data, creating vital risks by remotely managing the devices used in the medical field, and using personal phones for attack by misdirecting them with internet of things.

When the research data examining the threats to the physical health of the individual with the widespread use of $5 \mathrm{G}$ technologies are evaluated; It is widely accepted that some of the threats against the physical health of the individual will affect the psychology of the individual directly and some of them indirectly (Neuropsychiatry Portal, 2019; Davutoğlu \& Akgül, 2019; Ekovitrin, 2018).

In the new process where $5 \mathrm{G}$ technologies will be widely used, first of all in individual psychology; in the self-design of the individual, a change and transformation is expected that emphasizes/develops self-centered, introverted, asocial, technological knowledge and technological tool-oriented personality structure and features. Secondly; in this new process, there will be a decrease in the 'Real Individuality Awareness Level'; it is predicted that the proportion of individuals who experience 'Ideal Individuality' instead of 'Real Individuality' will increase. Decreasing the level of real self-awareness in individuals and increasing the ideal self-awareness level may increase the tendency of being self-centered, introverted and asocial by causing significant breaks in the individual psychology, and thus may cause a change in the personality traits of the individual. As the third; it is expected that the individual who uses 5G technology effectively will spend considerable time in obtaining technological information and using technological tools, as a result, the tendency of the individual to move away from socio-cultural and artistic activities will increase. It is anticipated that there will be permanent and radical changes in the psychological state and personality traits of the individual in the medium and long term, which gradually diverges from socio-cultural and artistic activities.

Both individuals and the social structure will be affected by this development as the psychology of the individual, who uses effective 5G technologies and can spread, changes and the number of these individuals increases. Individuals in society will increase their technological knowledge levels and technological vehicle usage rates in order to keep up with these developments. There will be a significant change in the technological knowledge and use level of the societies experiencing this process, in the education and training system, in their institutional and cultural structures, and accordingly, there will be a differentiation in the level of development. 


\section{Discussion}

The fifth-generation information and communication technologies, called 5G, are expected to be fully implemented soon. Today, trials for $5 \mathrm{G}$ are carried out in developed countries. Turkey, meanwhile, is expected to use $5 \mathrm{G}$ in 2020 . When $5 \mathrm{G}$ is fully available, it is anticipated that radical change and transformation will take place in many areas from production methods to education understanding in social life. With this process, significant changes in both social life and individuals' daily life will affect the psychology of individuals deeply. In this case, individuals need to adapt to the new process. It is anticipated that the adaptation process will be shaped according to the socio-cultural structure of the society and the perspective of individuals in the society towards technology.

When scientific research on this subject is examined; in the process where $5 \mathrm{G}$ technologies will be widely used, individual psychology will be affected, it is anticipated that a significant, multi-faceted change will occur in individual psychology. In this study, high probability changes predicted to occur in individual psychology are examined in three parts. Firstly; it is anticipated that individual self-design will gain weight with high level of technology knowledge of individuals, spending more time with technological equipment (according to current process), adopting or accepting self-centered asocial and introverted personality features. Secondly; adopting or accepting ideal individuality characteristics instead of real individuality, the transformation of the psychology of the individual, who adopts or accepts personality traits with low real individuality level, is expected to become widespread. Thirdly; it is predicted that individuals' personality traits, which tend to move away from socio-cultural and artistic activities, will become widespread.

In this study, a literature review was conducted for the compilation of secondary data, followed by tertiary and fictional data development studies. When evaluated within this scope; as the method of the study is limited because it is limited to obtain primary data in the study; descriptive research method and editing method were applied together. In the study, it is recommended that the subject will make original models by compiling and/or developing primary data within the scope of developments to the researchers who will examine this subject in the following processes.

\section{References}

Akgül, B. (2019). Possible Effects of the Development and Use of Artificial Intelligence Intended for Journalism Sector. Journal of Multidisciplinary Developments, 4(1), 57-64.

Akgül, B., \& Ayer, Z. (2020). The Change in the Management Structure of Media Institutions in the Fourth Industrial Revolution (Industry 4.0) Process. Journal of Life Economics, 7(2), 151-160. https://doi.org/10.15637/jlecon.7.010

Akgül, B., Ayer, Z., Turşucuoğlu, B., \& Yildiz, E. E. (2019). Developing Education Programs for Primary and Secondary Education Institutions of Journalism in Industry 4.0 Process. Journal of Multidisciplinary Developments, 4(1), 65-79.

BBC. (2018). Günlük Hayatımızın Parçası 5 Radyasyon Kaynă̆ı. Retrieved February 12, 
2020, from https://www.bbc.com/turkce/haberler-dunya-43329777

Campanaro, A. (2018). What is 5G? The Next Wireless Revolution Explained. Retrieved February 10, 2020, from https://www.nbcnews.com/mach/tech/what-5g-next-wireless-revol ution-explained-ncna855816

Campbell, K., Diffley, J., Flanagan, B., Morelli, B., O’neil, B., \& Sideco, F. (2017). The 5G Economy: How 5G Technology Will Contribute to the Global Economy. Retrieved February 11, 2020, from https://cdn.ihs.com/www/pdf/ihs-technology-5g-economic-impact-study.pdf

Collins English Dictionary. (2020). Technophobia. Retrieved February 14, 2020, from https://www.collinsdictionary.com/dictionary/english/technophobia

Davutoğlu, N. A., \& Akgül, B. (2019). Dördüncü Sanayi Devrimi’nin (Sanayi 4.0) Oluşum Sürecinde Üretim Faktörlerinin Yapısındaki Değişim ve Olası Yeni Üretim Faktörleri. Journal of Social And Humanities Sciences Research, 6(42), 2543-2558. https://doi.org/ $10.26450 /$ jshsr. 1370

Ekovitrin. (2018). Raporu TÜSİAD ve Marsh Türkiye Açıladı: Küresel Riskler Artıyor. Retrieved February 10, 2020, from http://www.ekovitrin.com/dergi2018/mayis/kureselriskler.pdf

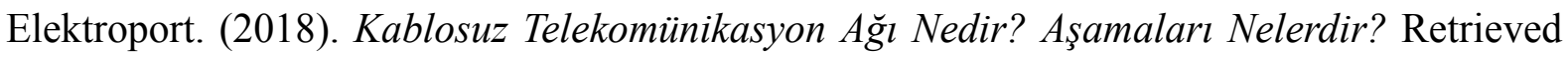
February 11, 2020, from https://www.elektrikport.com/haber-roportaj/kablosuz-telekomunika syon-agi-nedir-asamalari-nelerdir/21803\#ad-image-0 0

Ericsson. (2019). Ericsson Mobility Report November 2019. Retrieved February 12, 2020, from https://www.ericsson.com/4acd7e/assets/local/mobility-report/documents/2019/emr-nov ember-2019.pdf

Gerçek Hayat. (2019). 5G'nin Sonsuz İhtimalleri. Retrieved February 11, 2020, from http://www.gercekhayat.com.tr/roportaj/5gnin-sonsuz-ihtimalleri

Indus Net Technologies. (2016). What is Technophobia and How to Overcome It? Retrieved February 12, 2020, from https://www.indusnet.co.in/what-is-technophobia-and-how-toovercome-it

MEB (Milli Eğitim Bakanlı̆̆g). (2011). Kablosuz Ă̆ Sistemleri. Retrieved February 9, 2020, from http://www.megep.meb.gov.tr/mte_program_modul/moduller_pdf $/$ Kablosuz $\% 20 \mathrm{~A} \%$ C4\%9F\%20Sistemleri.pdf

Michel, A. (2018). How Technology Shapes Thoughts, Feelings, And Actions. Retrieved February 7, 2020, from https://www.psychologicalscience.org/observer/how-technologyshapes-thoughts-feelings-and-actions

Nöropsikiyatri Portal1. (2019). Retrieved February 10, 2020, from https://www.e-psikiyatri. com/cep-telefonu-bildiginizden-daha-zararli

Patel, K. K., Patel, S. M., Scholar, P. G., \& Salazar, C. (2016). Internet of Things-IoT: Definition, Characteristics, Architecture, Enabling Technologies, Application \& Future 


\section{Macrothink}

Challenges. International Journal of Engineering Science and Computing, 6(5), 6122-6131. Retrieved February 8, 2020, from https://www.researchgate.net/publication/330425585 Internet_of_Things-IOT_Definition_Characteristics_Architecture_Enabling_Technologies_A pplication_Future_Challenges

Rathod, R. (2014). Mobile Generations-0G, 1G. Retrieved May 14, 2020, from https://myphonefactor.in/2012/02/mobile-generations

Ronit, P. (2011). Technophilia: A New Model For Technology Adoption. UK Academy for Information Systems Conference Proceedings 2011 (Paper 41). Retrieved February 13, 2020, from https://www.researchgate.net/publication/235008115_Technophilia_A_New_Model_for _Technology_Adoption?enrichId=rgreq-5568fad6200618d055f4425780179065-XXX\&enric hSource=Y292ZXJQYWd1OzIzNTAwODExNTtBUzo5OTAxNjIwNTQwNjIyMUAxNDAw

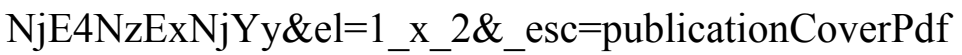

UHA (Üsküdar Haber Ajansı). (2018). 5 G Beraberinde Sorunları da Getirecek! Retrieved February 8, 2020, from https://uskudar.edu.tr/tr/icerik/3462/5-g-beraberinde-sorunlari-dagetirecek

Wikipedia. (2019). 1G. Retrieved February 10, 2020, from https://en.wikipedia.org/wiki/1G

Wikipedia. (2019). Femtocell. Retrieved February 8, 2020, from https://en.wikipedia.org/wiki/ Femtocell

\section{Notes}

Note 1 . The generally accepted definition of the concept of the Internet of Things (IoT) is as follows: The Internet of Things is the network of physical objects (Patel et al., 2016: 6122).

Note 2. In telecommunications, a femtocell is a small, low-power cellular base station, usually designed for use in a home or small business. A broader term, more common in the industry, is a small cell that contains femtocell as a sub cell (Wikipedia, 2020).

\section{Copyright Disclaimer}

Copyright for this article is retained by the author(s), with first publication rights granted to the journal.

This is an open-access article distributed under the terms and conditions of the Creative Commons Attribution license (http://creativecommons.org/licenses/by/3.0/). 